\title{
1939-1950 Yılları Arasında Türkiye'de Veremle Mücadele Faaliyetleri
}

\author{
Ahmet Coşkun Tekin ${ }^{1}$ \\ Düzce University, PhD Student, Department of History, Düzce, Turkey \\ Received- Accepted: 07.11.2018-20.12.2018 \\ Research Article
}

$\ddot{O} \mathbf{z}$

Salgın hastalıklar dünya tarihinde çok sayıda insanı ölmesine neden olmuştur. Özellikle savaş, doğal afet, kitllk ve ekonomik skkıntılar salgın hastalkların yayılmasını kolaylaştırmıştır. II. Dünya Savaşı’nın başlaması tüm dünyada olumsuz dưumların ortaya çikmasına neden olmuştur. Türkiye her ne kadar savaşa katılmamış olsa da savaştan nasibini almış, ülkede ekonomik ve sosyal alanda skintılar baş göstermiştir. Ülkede üretim faaliyetleri azalmış, ekonomi bozulmuş, gida skintılları başlamış ve bunlara paralel olarak salgın hastalkklarda artış meydana gelmiştir. Özellikle bu süreçte ölümün kaptanı olarak tanımlanan verem hastalı̆ı ülkenin pek çok yerine yayılmış, hastalı̆g bağlı ölümler her geçen gün artmıştr. Yaşanan bu gelişmelere bağlı olarak ülkede verem hastalığına karşı topyekûn bir savaş başlatılımıștır. Bu çalışmada Türkiye'de verem hastalığına karşı ne gibi önlemler alındığı, devletin ve halkın verem hastalğı ile ilgili mücadele yöntemleri tespit edilmeye çalşsılmıştr. Özellikle Başbakanlk Cumhuriyet Arşivi'nden yararlanılarak veremle ilgili ulaşlabilen kaynaklar değerlendirilmiştir. Ayrıca Türkiye Büyük Millet Meclisi Tutanak Dergisindeki konuşma zabtlları doğrultusunda milletvekillerinin seçim yerleri, Türkiye'deki verem hastalığı ve bu hastalkla mücadelenin boyutu tespit edilmeye çalışılmıştr.

Anahtar Kelimeler: Türkiye, Salgnn Hastalk, Verem, Sanatoryum, Verem Savaş Dernekleri

\section{The Struggle of Tuberculosis Activities Between the Years of 1939-1950 in Turkey}

\begin{abstract}
The epidemics cause many people to die in the world history. Especially, wars, natural disasters, famine and financial problems make easier to spread the epidemics. The begining of the World War II causes negative conditons to arise in the whole world. Turkey has its share of the war even though it does not participate in war, the problems arise in the field of economic and social in the country. Production activities decrease, economic dislocation, food storage begins and the epidemics increase concordantly. Tuberculosis which is described the captain of death spreads all over the country and the death rate which is related to the illness increases day by day. After these bad conditions, it is started a big war against the tuberculosis in the country. In this study, it is studied to determine the methods of struggle with tuberculosis of public and the government and what sort of precautions are taken against the tuberculosis in Turkey. Especially, the resources which are related to the tuberculosis in the Prime Ministery Republic archives are determined. Furthermore, in accordance with the official reports of Turkish Grand National Assembly magazine; deputies' election places and tuberculosis thoroughout Turkey and the struggle of this disease's rate is tried to determine.
\end{abstract}

Key words: Turkey, Epidemics, Tuberculosis, Sanatorium, Tuberculosis Associations.

\footnotetext{
${ }^{1}$ acoskuntekin@gmail.com, ORCID: 0000-0003-1589-7714, This article is analyzed by three reviewers and it is screened for the resembalance rate by the editor. (Bu makale üç hakem tarafından incelenmiş ve editör tarafından benzerlik oranı taramasından geçirilmiştir)
} 


\section{Giriş}

Cumhuriyetin ilk yıllarında, yoğun bir savaş döneminden çıkan Türkiye, bundan kaynaklı olarak ekonomi, sağlık, eğitim gibi pek çok alanda eksiklikler yaşamış ve bazı sıkıntılarla karşı karşıya kalmıştır. Bunlardan bir tanesi verem hastalığıdır ve ülke genelinde hastalığa karşı topyekûn bir mücadele başlatılmıştır (Kasapoğlu, 2016, s.136). 1923-1937 yılları arasında sağlık bakanı olarak görev yapan Dr. Refik Saydam, veremle ilgili başarılı işler hayata geçirmiştir. Bakanlık görevine başladığında sekiz maddelik bir sağlık programı hazırlamıştır. Programın 7. maddesi "Verem Sanatoryumu ve Akıl Hastanesi Açılması” olmuş, sağlık kuruluşlarının açılması hızlandırılmıştır (Yılmaz, 2014, s.63). 1923 yılında ilk verem savaş dispanseri Sağlı Bakanlığı'nın isteği ve onayı sonucunda hizmete başlamıştır. Belirlenen veremlilerin tedavi edilebilmesi amacıyla 1924 yılında elli yataklı Heybeliada Sanatoryumu faaliyete geçirilmiştir. Haydarpaşa ve İzmir'de bulaşıcı hastalıklar hastanelerinde, diğer devlet ve numune hastanelerinde de olanaklar ölçüsünde veremliler için ayrı yataklar tahsis edilmiştir (SBTHBM, 2004, s.8). Dr. Musa Kazım tarafindan 1923 yılında Büyükada'da ilk özel verem sanatoryumu, 1924 yllında Heybeliada'da açılmıştır. Daha sonraki yıllarda ise 1932'de Erenköy Sanatoryumu ve 1936'da İstanbul Yakacık’ta bir sanatoryum daha açılmıştır (Tuğluoğlu, 2008, s.11).

1925 yılında sağlık alanında düzenlemeler yapmak amacıyla Milli Tıp Kongresi düzenleme kararı alınmıştır. 1-3 Eylül 1925 tarihleri arasında gerçekleștirilen ilk kongrede ana gündem maddeleri sitma ve verem tedavisi olmuştur. 11-13 Eylül 1927 tarihleri arasında yapılan 2. Milli Tıp Kongresi'nde de verem tedavisi tartışılmıştır (Özkaya, 2016, s.78). Gerçekleştirilen bu kongreler sayesinde doktorlar verem hakkında bilgi paylaşımında bulunmuş ve veremle mücadele konusunda yapılması gerekenler masaya yatırılmıştır. Bunun yanında Cumhuriyetin ilk yıllarında veremle ilgili yurtdışndaki gelişmelerde takip edilmeye çalışılmıştır. Roma'da açılacak olan uluslararası verem sergisine katılım sağlanması istenmiştir (BCA 030.18.01.01/29.44.18). Ayrıca Dr. Tevfik Salim Paşa'nın Lahey'de 6 Eylül 1932 tarihinde düzenlenecek Uluslararası Verem Konferansı'na katılmasına izin verilmiş, konferans masrafları kendisine ait olmak üzere siyasi pasaport verilmesi onaylanmıştır (BCA 030.18.01.02/30.59.8). (bkz. Ek:1).

Türkiye'de ilk verem aşısı 1927 yılında ağız yoluyla uygulanmaya başlamıştır. Sağlık ve Sosyal Yardım Bakanlığı hastalıktan koruyucu olarak uygulanan verem aşısı üzerine çalışmalar yapmaya başlamıştır. Verem aşısı Refik Saydam Merkez Hıfzıssıhha Müessesinde hazırlanarak yeni doğan çocuklara uygulanmıştır. Fakat diğer yaştaki bireylere bu tarz bir aşılama yöntemi uygulanamayacağından aşı çalışmaları istenildiği şekilde geniş ölçüde yapılamamıştır. 1947 yılında tüm doğum evleri ve servislerine yeni doğan bebeklere uygulanmak üzere haftalık olarak verem aşısı gönderilmeye başlanmışıı, fakat ulaşımdan kaynaklı ortaya çıkan sorunlardan dolayı 1950 yılında bu uygulamadan vazgeçilmiştir (Hot, 2001, s.106-107).

Salgın hastalıklarla mücadeleyi teşvik edebilmek amacıyla koruyucu hizmetlerde çalışan doktor 
ve diğer sağlik personeline en yüksek kadrolar verilmiştir. Başbakandan daha fazla ödenek verilerek doktorlar hizmete özendirilmiştir. Doktor ve sağlik personeline yapılan bu iyileştirmeler çalışma verimini arttırmıştır. Bu dönemde veremle mücadele için 52.000 kişiye sağlık taraması yapılmıştır (Bektaş, 2006, s.202). 24 Nisan 1930 tarihinde Türkiye Cumhuriyeti'nin sağlık alanındaki en önemli adımlarından biri atılmış ve 1593 sayılı Umumi Hıfzıssıhha Kanunu çıkarılmıştır. Veremle mücadeleye ayrı bir önem verilen bu kanunla birlikte; Verem hastalarının ve bu hastalıktan ölenlerin kayıt altına alınması, veremli hastanın adres değişikliği yapması halinde gideceği yerdeki sıhhiye dairesine haber verilmesi gibi önlemler alınmıştır (Resmi Gazete, 06.05.1930, s.8895, 8901). Aynı zamanda sağlık alanındaki teknolojik gelişmelerde takip edilmiştir. 14 Mayıs 1930 tarihinde veremle mücadelede kullanılmak için iki adet röntgen makinesinin alınması onaylanmıştır (BCA 030.18.01.02/11.31.14). Kısa sürede Sağlı Bakanlığı tarafindan veremle mücadele konusunda yapılanlar meyvelerini vermiş ve 1930'lu yıllarda veremden ölen sayısında azalma kayıt edilmiştir. Ancak II. Dünya Savaşı'nın başlamasıyla ortaya çıkan sıkıntılara bağlı olarak veremden ölenlerin sayısı 1939-1948 yılları arasında yeniden artmaya başlamıştır (Özkara, 2010, s.37).

\section{9-1950 Yılları Arasında Veremle Mücadele Faaliyetleri}

Türkiye her ne kadar II. Dünya Savaşı'na katılmamış olsa da sosyal ve ekonomik sarsıntılar geçirmiştir. Temel tüketim maddelerine zamlar gelmiş, halk bunlan temin edemez olmuş, yeterli ve dengeli beslenememiştir (Çakırçoban, 2010, s.106). Buğday ve şeker gibi önemli yiyecekler bulunamamıştır. Yaşanan bu gelişmeler halk sağlığını olumsuz etkilemiş, yaşam kalitesinde düşüş yaşanmıştır. Ortaya çıkan beslenme yetersizlikleri ve evlerin hıfZıssıhhasının uygun olmayışı verem hastalığının yayılmasını hızlandırmıştır (Tuğluoğlu, 2008, s.6). Ülke nüfusunun \% 75'inin yaşadığı köylerde veremden ölen sayısı her geçen gün artmıştır (BCA 030.01.00.00/77.482.6). Nitekim 1949 yılında çıkarılan Verem Savaşı hakkındaki kanun tasarısının gerekçesinde de II. Dünya Savaşı'na vurgu yapılmıştır (Çufalı, 2012, s.389).

Verem dispanserleri, yaşanan kötü süreçte veremle mücadeledeki en önemli sağlı kuruluşlan olmuştur.Dispanserler aracılığgyla 20 bin ve 50 bin aralığında nüfusa sahip yerlerde veremin kontrol edilebileceği düşünülmüştür. Bu nedenle ilk olarak dispanser açılması için çaba sarf edilmiştir. Devletin, halkın ve Verem Savaş Derneklerinin desteğiyle birçok yeni dispanser açılmıştır. Örneğin; 1941 ylında İstanbul Verem Savaş Cemiyeti tarafindan Beykoz'da Subaşı Verem Dispanseri hizmete geçmiştir (Cumhuriyet, 20.07.1941, s.2). Açılan bu dispanserde fakir hastaların iyi beslenmeleri ve ihtiyaçlarını karşılayabilmeleri için Tan ve Opera sinemalarının sahipleri 15'er lira bağış yapmışlardır(Cumhuriyet, 25.07.1941, s.4). 29 Eylül 1945 tarihinde Bakanlar Kurulu tarafindan verilen kararla Ankara'da yapturlacak olan Verem Hastanesinde harcanmak üzere Türkiye Kızlay Derneği'ne 1,5 milyon lira verilmiştir (BCA 030.18.01.02/109.59.9). 1945 yılında İstanbul'daki bazı hayırsever işadamlan, işçiler için İstanbul'da yaptırlmasına karar verilen verem hastanesi ve dispanserinin giderleri için 27 bin lira bağışlamıştır (TBMMTD, 26.12.1946, s.9). İstanbul Verem Savaş Derneği tarafindan 
Kocamustafapaşa'da inşa ettirilen 11. Verem Dispanseri 1 Kasım 1948 tarihinde hasta kabulüne başlamıştr (Cumhuriyet, 02.11.1948, s.1). Elazığ’da kıstllı imkânlarla çalışan Elazı̆̆ Verem Savaş Derneği'ne Amerika'da çalş̧an Elazığlı vatandaşlar 21 bin dolar bağıssta bulunmuşlardır. Dernek bu sayede 20 yataklı bir dispanser kurmuştur ve kalan tutarın bir kısmı ile modern bir röntgen cihazı almak için girişimlerde bulunmuştur (Cumhuriyet, 23.03.1949, s.3). Türkiye'deki 1945 yllında toplam verem dispanseri sayısı 5 iken bu sayı 1948 yılında ki Sağlık Bakanlı̆̆ı ve Derneklerin çalışması sayesinde 46'ya ulaşmıştır (Özkan, 2010, s.680). 1939-1947 yllları arasında dispanserler aracıllı̆ıyla 338.385 kişi muayene edilmiş̧ir ve bunların 13.127'sinde verem hastalı̆ı tespit edilmiştir. 27.290 hastaya ücretsiz ilaç dağtımı yapılmış, yine aynı ylllar içerisinde 77.862 kişi röntgen muayenesi edilmiş̧ir (Hot. 2001, s.119).

Devlet, dispanserlerden başka verem pavyonlanı da faaliyete geçirmiş̧ir. 1939 yllında Haydarpaşa Numune Hastanesi'ne 140 yataklı, Heybeliada Sanatoryumuna 200 yataklı verem pavyonu inşası için Sağılk Bakanlı̆ı̆ onay vermiştir (Cumhuriyet, 11.07.1939). 1940 ylında İzmir Tepecik'te bulunan Emraz-i Sâriye Hastanesine ilave olarak inşa edilen 50 yataklı verem pavyonunun açilş̧ töreni yapılmıştr. Bu pavyon modern sağık ekipmanları ile donatılmıştr. Geniş bir sanatoryumu, gelişmiş hava düzeneği olan odaları ve hususi banyoları olan, sadece İzmir'in değil tüm bölgenin ihtiyacını kısmen karşlayacak bir şekilde dizayn edilmiştir (Cumhuriyet, 17.07.1940, s.3). 1941 yllında hastanenin yatak kapasitesi arttrılarak 75'e çıkarılmış ve adı değiştirilerek İzmir Bulaşııı ve Salgın Hastalıklar Devlet Hastanesi olmuştur (Didem, 2014, s.432).

Devlet tam bu süreçte verem hastalı̆ııın yarattığı tehlikenin farkında olarak eldeki imkânları olabildiğince kullanmaya çalışmışır. Örneğin; ülkede ortaya çıkan ekonomik bunalım bazı alanlarda tasarruf tedbirleri alınmasına neden olmuş, ekmek karneye bağlanmıştr. 7 yaşından küçük çocuklar için 187,5 gram ekmek, 7 yaşından büyüklere 375 gram ekmek, prevantoryum, sanatoryum ve hastanelerde yatan verem hastaları için 450 gram ekmek verilmesi kararı alınmışsır(Kayış, 2009, s.15). Verilen ekmek miktarlarında 24 Mart 1945 tarihinde bir değişiklik yapılmıştr ve verem hastalığndan hastanelerde tedavi görenlere 600 gram ekmek alabilme hakkı verilmiş̧ir (Dokuyan, 2013, s.200). Bu durum bile devletin verem hastalı̆ğna verdiği önemin mühim bir göstergesidir.

Dr. Behçet Salih Uz bakanlı̆ı döneminde veremle mücadele konusunda önemli atılımların da yer aldığı, cumhuriyet tarihinin ilk yazılı sağık planı olduğu belirtilen “1. On Yıllık Sağık Planı" Yüksek Sağılk Şurası tarafindan onaylanmıştr. Plan, 12 Aralı 1946 tarihinde Dr. Behçet Salih Uz tarafindan kamuoyu ile paylaşılmış fakat ciddi bir hazırlık süreci sonucunda ortaya çıkan bu plan Dr. Behçet Salih Uz'un Bakanlık görevinden ayrlmasıyla rafa kaldırlmıştr. Dr. Behçet Salih Uz'un ikinci bakanlık döneminde plan kanun tasarısı olarak hazırlanmış olsa da kanun haline getirilememiştir (Illeri, Seçer, vd. 2016, s.179).

1947 yllından itibaren eğitim ve propaganda faaliyetleri sayesinde halk bilinçlendirilmeye 
Journal of Universal History Studies (JUHIS) • Vol. I • Issue 1 • 2018 • pp. 1-21

çalışılmıştır (Özkara, 2010, s.669). Sağlık ve Sosyal Yardım Bakanlığı halkı bilinçlendirmek amacıyla ilk defa 3-9 Ocak 1948 tarihleri arasında "Verem Haftası" düzenlemiştir. Bakanlık Verem Haftası tarihleri arasında Halk Evlerine bir yazı göndererek verem hakkında konferanslar düzenlenmesini ve halkın bu konuda bilinçlendirilmesini istemiştir (BCA 490.01.00.00/08.41.4).

1948 yılında veremle mücadele konusunda daha somut adımlar atılmaya başlanmıştır. Çıkarılan kanunlar, bilimsel gelişmeler, personel eksikliklerinin farkında olarak atılan adımlar ve siyasilerin veremden kaynaklı sıkıntıları dile getirmeleri bunun bir göstergesidir. 1948 yılında veremden korunma programı doğrultusunda yapılan çalışmalar sonucunda Ankara'da Refik Saydam Hıfzıssıhha Enstitüsü’nde BCG aşısı üretilmeye başlanmıştır (Vidinel, 2010, s.21). Nitelikli sağlık personeline ihtiyaç olduğundan, personel sayısının artırılması konusunda çalışmalar başlatılmış hatta 2 Haziran 1948 tarihinde çıkarılan kararla Avustralyalı Katarına Thetter'ın Heybeliada Verem sanatoryumunda iki yıl süreyle başhemşire olarak çalıştırılmasına izin verilmiştir (BCA 030.18.01.02/116.38.2). 17 Ocak 1949 tarihinde Verem Savaş İstişare Komisyonunda Milli Savunma Bakanlığı temsilcisi olarak görev yapan Prof. Dr. Nusret Karaca'nın yaptığ teklif doğrultusunda veremle mücadele amacıyla açılan dispanser ve hastanelere, verem konusunda uzman doktorların yetişmesi için tıp fakültelerinde tüberküloz(verem) kürsüsü kurulması kabul edilmiştir (Vidinel, 2010, s.22).

1948 yılında dönemin iktidar partisi CHP, verem hastalı̆̆ı ile ilgili daha ciddi adımlar atılması gerektiğinin farkına varmış ve parti grubunda verem hastalığı görüşülmüştür. Başbakan Hasan Saka bu konuda bir konuşma yapmıştır ve veremle ilgili bir raporu dinleyicilere okumuştur. Hızlı bir şekilde mücadeleye başlanması gerekildiğini ve parti grubundan bu konuyla ilgili çalışmalar yapacak bir komisyon hazırlanması teklif edilmiştir. Neticesinde veremle mücadele konusunda 200 milyon liraya ihtiyaç olduğu belirtmiştir ve hükümetin bu konuda çalışma yapması kararı alınmıştır. Bu konu ile ilgili olarak Şefik Tugay, İsmail Hakkı Baltacıoğlu, Dr. Aziz Uraz ve Hıfzı Oğuz Bekata veremle mücadelenin önemini belirten konuşmalar yapmıştır (Cumhuriyet, 01.12.1948, s.1, 3).

1949 yılında Birinci Verem Savaş Danışma Kurulu toplanmıştır. Bu toplantıda hastane ve sanatoryumlardaki verem hastalarının yatak sayısının arttırılmasına karar verilmiş ve 1950'li yıllarda yatak sayısında ciddi artış olmuştur. Buna ilaveten Türkiye'nin pek çok yerinde yeni hastaneler açılmıştır (Özkara, 2010, s.662). Verem hastalı̆̆ının bulaşmasına engel olmak için tedbirler alınmıştır. Bulaşma olasılığının en fazla olduğu yerlerden bir tanesi olan okullarda önlemler alınmaya başlanmıştır. Örneğin İstanbul Üniversitesi, 1948 yllında üniversiteye girmek isteyen öğrencilerin röntgen muayenesinden geçmesini zorunlu hale getirmiştir. Nitekim, İstanbul Verem Savaşı Derneği'nin röntgen arabasıyla muayene edilen öğrencilerin yüzde 0,82 oranında verem hastalığı tespit edilmiştir (Hot, 2001, s.115).

1949 yll içerisinde ülke genelinde, üniversitelerde verem konusunda uzman profesörlerin başkanlığında genel verem sağlık taraması yapılması kararı alınmıştır. Yapılan bu tarama ile veremin yayılma mıntıkaları tespit edilerek gerekli önlemlerin alınmasına karar verilmiştir. Bunun yanında üç yıl 
boyunca uygulanacak veremle mücadele programı hazırlanmıştr. $\mathrm{Bu}$ programa göre; ülkenin verem hastalarının ihtiyacı olan 4000 yataklı verem hastaneleri açılarak temin edilecektir. Bu hastaneler, bölgelerdeki hastalı̆ın şiddet derecesine göre siraya koyularak inşa edilecektir. Planların hayata geçirilebilmesi için bütçeden 1949 ylında 12 milyon, 1950 yllında 6 milyon, 1951 yllında 3,5 milyon ayrılmıştır. 1949 yllında Erzurum, Rize, Trabzon, Edirne, Bursa, Balıkesir, Kayseri ve Malatya'da hastane ve dispanser kurulmasına karar verilmiştir. 1950 ylında Sivas, Samsun, Giresun, Çanakkale, Denizli, Seyhan ve Diyarbakır'da 1951 yllında ise Elazı̆̆, Konya, Bolu, Aydın ve Tekirdağ'da veremle mücadele için sağlık kuruluşlarn açllacaktır (Cumhuriyet, 20.12.1948, s.1).

\section{Dünyada ve Türkiye'de Veremden Ölüm Oranlan}

O yllarda verem sadece Türkiye'de görülen bir hastalık olmayip, dünyanın genelinde çok sayıda insanın ölümüne neden olan en önemli salgın hastalıklarnndandır. Verem hastalığı yaş sinılaması olmaksızın tüm insanlanı etkileyen bir özelliğe sahiptir (SBTHGM, 2004, s.7). Verem hastalarının sayısı ve ölenler hakkında devletler istatistik çalışmaları yapmıştr. Bu doğrultuda hastalığn yoğun olduğu yerler tespit edilmiş ve bu yerlere öncelik verilmiş̧ir. Türkiye'nin veremden ölüm istatistikleri incelendiğinde ülke genelinde durumun hiç iç açıcı olmadığ görülmektedir.

1931-1939 yılları arasında Türkiye'de veremden ölenlerin sayısı 22.562'dir. Ölüm oranı ise yüz binde 166'dır. 1931 yllında İstanbul'da veremden ölüm oranı yüz binde 220, 1939 ylında yüz binde 187’ye gerilemiştir. Fakat II. Dünya Savaşı ve sonrasında ölüm saylları artmış ve ölüm oranı 1947 yllında yüz binde 149 olmuştur. Ankara'da 1931 ylında yüz binde 79, 1939 ylında yüz binde 110 olmuştur. Bu rakam 1947 ylında yüz binde 149'a ulaşmıştır. II. Dünya Savaşı'ndan kaynaklı olarak yaşam koşullarııın sikıntıya girmesi ölüm oranlarnnda artışa neden olmuştur (Hot, 2001, s.111). Özellikle savaşın ilk ylllarnda bebek ve çocuklar yeterli beslenememiş, bu nedenle verem en büyük etkiyi onlar üzerinde yapmıştr. 3-15 yaş aralığndaki çocuklar arasındaki verem oranı savaş öncesi dönemle kıyaslandı̆gnnda \% 30 artış göstermiştir. Savaşın başladığ ilk yl Ankara'da veremden ölüm oranı yüz binde 91'e yükselmiş̧ir. Bu oran İzmir'de yüz binde 252, Aydın'da yüz binde 62, Manisa'da yüz binde 146, Edime'de yüz binde 171, Konya'da yüz binde 56, Adana'da yüz binde 66, Bursa'da yüz binde 130, Eskişehir'de yüz binde 90 , Trabzon'da ise yüz binde 112'ye ulaşmıştr (Çobançakır, 2010, s.106).

1942 ylında 25 şehirde verem hastalığ hakkında yapılan bir istatistik çalışmasında şu verilere ulaşlıııştr. (Bkz: Ek:2) 1940 nüfus sayımına göre yirmi beş şehirdeki toplam nüfus sayısı 2.913.202'dir. 1942 yllnda veremden ölenlerin toplam sayıs 5.083 'tür. Veremden en çok ölümün gerçekleştiği şehir 2.534 kişiyle İstanbul olmuştur. İzmir şehri 608 kişiyle ikinci srradadır. 100 bin kişi içerisinde 410,2 oranıyla veremden ölüm oranının en yüksek olduğu yer Çanakkale'dir (BCA 030.01.00.00/77.482.6.6). İstatistiksel verilere göre 25 büyük şehirde, 1942 yllında veremden ölenlerin sayısı ile 1940 genel nüfus sayımı rakamları kıyaslandığnda, veremden yüz binde ölüm oranı 96,5 ile 410,2 arasında değişiklik 

olduğu tespite göre Ankara, Bursa, Eskişehir, İstanbul ve İzmir şehirlerinde veremden ölenlerin sayısı oranlara göre yüksek çıkmıştır. Ülkenin genel ölüm oranları ortalaması yüzde 13,5 olarak belirlenmiştir (SGTHGM, 2004, s.8).

Sağlık ve Sosyal Hizmetler Bakanı Dr. Behçet Salih Uz’un açıkladığı, 1941 yılı dünya verem istatistiklerine göre her yüz bin nüfusa Londra'da 52, Madrid'de 105, Paris'te 215, Brüksel'de 98, İsviçre'de 76 ve Bulgaristan'da 163 veremli isabet etmesine karşıllk bu oran Ankara'da 44, İstanbul'da 195 ve İzmir 'de ise 64 dür. Ayrıca 31 şehirde yapılan istatistiklere göre yüz bin nüfusta ölüm nispeti 198'dir (TBMMTD, 26.12.1946, s.572-573).

II. Dünya Savaşı'ndan sonra 1946 yılında Washington Public Health bazı ülkelerde verem hastalığının yüz binde kaç kişi olduğunu tespit etmiştir. Buna göre; Danimarka'da 34, Avustralya'da 40, Hollanda'da 41, ABD'de 47, Almanya'da 50, Misir'da 52, Yeni Zelanda'da 60, İngiltere'de 62, Uruguay'da 101, Arjantin'de 103, İspanya'da 122, Çekoslovakya'da 124, Romanya'da 162, Finlandiya'da 190, Polonya'da 195, Türkiye'de 198, Brezilya'da 250, Hindistan'da 283, Çin'de 430, Alaska'da 437'dir (BCA 030.01.00.00/77.482.6.5). (Bkz. Ek:3) Bu oranlar incelendiğinde Türkiye'nin verem hastalığı hususunda dünya ortalamasında olduğu görülmektedir.

\section{Veremle Mücadelede Uluslararası İlişkiler}

Türkiye Cumhuriyeti veremle mücadele konusunda dünyadaki gelişmeleri takip etmeye çalışmışır. Bunun için alanında uzman kişiler Türkiye'ye davet edilmiştir. Bazı durumlarda ise Türk hekimler yurtdışına gönderilerek incelemelerde bulunmuş, öğrendikleri yenilikleri ülkemizde uygulamaya çalışmıştır.

Örneğin; 1948 yılında Sağlık ve Sosyal Yardım Bakanlığı tarafindan, üç tane verem uzmanı hekim, verem aşısı hakkında bilgilerini geliştirmeleri için yurtdışına gönderilmiştir. Gönderilen doktorlar özellikle aşının en fazla yapıldığı ülkelerde çalışmalar yapmıştır. Geri döndüklerinde iki ay kadar çeşitli hastanelerde çalıştırılmış, ardından verem aşısı istasyonlarının başına getirilmişlerdir.Bu hekimle daha sonra Ankara, İstanbul ve İzmir'de kurulan verem aşısı istasyonlarında ücretsiz olarak aşılama yapılmıştır. Halk ücretsiz verem aşısına büyük bir ilgi göstermiştir. İstanbul'da Haseki Darüşşifasında kurulan aşı istasyonu müdürü Dr. Nureddin Onur kendisiyle yapılan röportajda, verem aşısını uygulamaya başlayalı üç gün olmasına rağmen halkın çok fazla ilgi gösterdiğini ve bu durumun kendilerini sevindirdiğini belirtmiştir (Cumhuriyet, 09.12.1948, s.4).

Veremle mücadelede uluslararası işbirliği çalışmaları yapılmıştır. Bu doğrultuda 1948 yılında Birleşmiş Milletler Dünya Sağlık Teşkilatı Yunanistan temsilcisi Avusturyalı Dr. Vıne, Sağlık Bakanlığı tarafindan Türkiye'ye davet edilmiştir. Dr. Vine'e Türkiye'nin genel sağlık kurumları ile veremle mücadele kuruluşlarında yapılanları incelemesi ve bir rapor hazırlaması istenmiştir (Cumhuriyet, 07.10.1948, s.2). Dr. Vine bu isteği kabul ederek Türkiye’ye gelmiş, yaklaşık bir ay süren incelemelerde 
bulunmuş,ülkenin pek çok yerindeki sağlk kuruluşlarını dolaşmıştrt. Yaptı̆̆ tetkikat neticesinde elde ettiği bilgileri basın mensuplarıla paylaşan Dr. Vine tespitlerini şu şekilde sıralamıştr; ziyaretçi ve gezici hemşirelerin köylere gönderilmesini tavsiye etmiş ve bunun verem gibi salgın hastalıkları önleyebileceğini söylemiştir. Cumhurbaşkanı ve hükümetin işi ciddiye aldığını belirten Dr. Vine verem hastalarına tahsis edilecek yatak sayısının yetersiz olduğunu ifade etmiş, hastane, sanatoryum ve dispanserlerde çalışacak hemşire ve doktor sayısının arttıııması gerektiğini belirtmiş̧tir. Diplomalı hemşire sayısının az olması Türkiye'nin sağlk alanındaki en büyük eksikliği olduğunu ifade eden Dr. Vine sahip olmast gereken hemşire miktarının ihtiyacın çok altında olduğu dolayısıyla uygun illerde hemşire okulları açılması gerektiğini tavsiye etmiş̧tir (Cumhuriyet, 10.10.1948, s.6).

İsviçre'nin tanınmış verem uzmanlarndan Dr. Mauren de Türkiye'de davet edilmiş ve "Veremin Yeni Usullerle Tedavisi” hakkında konferans vermesi istenmiştir. Dr. Mauren 25 Kasım 1948 tarihinde İstanbul'a gelerek bu konuda konferanslar vermiștir (Cumhuriyet, 13.11.1948, s.3).

Bu hekimlerin haricinde Londra Hastaneleri Başhemşiresi Miss E.E.P Momanus da davet üzerine Türkiye'ye gelmiş̧ir. Miss Momanus'un hemşire okullan ve hemşire yetiştirme programları hakkındaçeşitli incelemelerde bulunması, konferanslar düzenlemesi istenmiş̧ir (Cumhuriyet, 10.02.1949 s.4). Yaptı̆̆ incelemeler sonucunda veremle mücadele hakkında açıklamalarda bulunan hemşire Momanus, Türkiye'deki veremle mücadele sağlk kuruluşlarının sayısının arttırlması, Sağılk kuruluşlarında verem tarama muayeneleri yapılması, muayenesi yapilanlara fiş hazırlanması ve gerektiğinde bu fişlerle her yll düzenli bir takip sistemi oluşturulmast yönünde tavsiyelerde bulunmuş̧ur. Hastanelerin bazılarında aynı yatakta iki tane hasta yatırıldığııı belirten Momanus, bu uygulamadan bir an önce vazgeçilmesi gerektiğini, veremle savaşta gida kontrollerinin iyi yapılması gerektiğini ilave etmiştir. Hemşirelerin yardımcısı olarak çalışan hasta bakıcılarını pek basit insanlar olarak gören ve hastalara çok sert davrandıklarına dair duyumlar alan Momanus bu davranışın yanlış olduğunu da belirtmiş, hastanın ilk tedavisinin şefkat ve tatlı dil olduğunu söylemiştir (Cumhuriyet, 24.02.1949, s.4).

Son olarak, 1950 yllında Birleşmiş Milletler (BM) sağık teşkilatı üyesi bir heyet İstanbul'a gelmiş ve buradaki laborant okullarında ve verem dispanserlerinde incelemelerde bulunmuştur. Yaptkları incelemeler sonucunda kuruluşları beğendiklerini ifade etmiş̧lerdir (Cumhuriyet, 29.01.1950, s.2). Daha önceden gelen uzmanlar yaptkları incelemelerde genel manada eleştirilerde bulunmuş olsalar da bu defa kurumların beğenilmiş olması veremle mücadelede atılan adımların olumlu yönde geliştiğinin bir göstergesidir. İncelemelerin yapılmasından kısa süre sonra 16 Şubat 1950 tarihinde BM Dünya Sağık Teşkilatı tarafindan veremle mücadele personeli yetiştirme ve gösteri merkezi kurulması için Bakanlar Kurulu tarafindan Sağlk ve Sosyal Hizmetler Bakanlığnna yetki verilmiştir (Cumhuriyet, 29.01.1950, s.2).

\section{Veremle Mücadelede Sivil Toplum Kuruluşlarn ve Faaliyetleri}

Verem hastalı̆̆ konusunda Türkiye'de en ciddi mücadeleyi veren sivil toplum kuruluşu (STK) 
derneklerdir. Bu nedenle ülkenin pek çok yerinde veremle mücadele edebilmek amacıyla dernekler kurulmuştur. Kurulan bu dernekler Türkiye'de uzun yllar Sağlık Bakanllğı ile işbirliği içinde hareket etmişlerdir. Derneklerin tedavi boyunca hastayı ödüllendirme, sosyal ve ekonomik destek sağlamak gibi önemli işlevleri de olmuştur (Özkara, 2003, s.40, 90).

Türkiye'de ilk veremle mücadele derneği 18 Şubat 1923 ylında çocuk hastalklanı uzmanı Dr. Behçet Salih Uz tarafindan İzmir'de kurulmuştur. Yine 1923 yllında Balkesir'in ileri gelenleri tarafindan Verem Savaş Derneği faaliyete geçmiştir (Gürgan, 2013, s.139). Kurulan bu dernekler dışında çalışmalarıla dikkat çeken, Türkiye'deki veremle mücadele konusunda çok önemli çalşsmaları olan İstanbul Veremle Mücadele Cemiyeti 1927 yllında kurulmuştur (Tuğluoğlu, 2008, s.10). Daha sonraki yllarda ismi İstanbul Veremle Mücadele Derneği olan bu kuruluş, halkın bilinçlenmesine çok önem vererek "Yaşamak Yolu" adında bir dergi de çıkarmıştr. 1940 ylında "Verem pulu" bastırlmaya başlanmış ve bu sayede 1941 yllında 40.216 lira, 1945 yllında 323.531 lira gelir elde edilmiştir (Yllmaz, 2014, s.68). İstanbul sinemaciları, Verem Mücadele Cemiyeti'nin ülke sağığı için yaptığı önemli çalışmaları görerek, sinemaya gelenlere cemiyetin yardım pullarıı almaları için teklifte bulunacaklarını taahhüt etmişlerdir. Bu sayede cemiyete önemli miktarda gelir sağlanmıştr. Lokantacllar ve otelcilerde aynı şekilde uygulamaya başlamışlardır (Cumhuriyet, 6.12.1940, s.2). 1943 yllında İstanbul Verem Savaşı Derneği tarafindan ilk kez "Verem Savaşı Hemşire Okulu " açılmıştr. Bu okulda başlangçta eğitim iki yl olarak belirlenmiş, daha sonra süre dört ylla uzatılmıştr. Kız öğrenciler parasız yatılı olarak bu okulda eğitim almıştr. İstanbul Verem Savaşı Derneği, verem hakkında dünyadaki gelişmeleri takip edebilmek amacıyla çok sayıda doktor ve sağlk personeline burs vermiş, bunları yurt dışnda eğitime göndermiş̧ir (Killçarslan, 2010, s.677-678). Derneğin faaliyetleri aynı zamanda bağış yoluyla da desteklenmiş̧ir. 1942 yilında yapımına başlanacak olan verem hastanesi için Karabük Demir ve Çelik Fabrikasından 15 ton, İstanbul'daki Sazmaş Şirketi'nden 10 ton ve ithal edilen demirlerden 25 ton olmak üzere toplamda 50 ton demir İstanbul Verem Savaşı Derneği'ne verilmiş̧ir (BCA 030.00.00.00/179.235.24). 1949 yilında Naile Sağlam'ın yapmış olduğu bağısla İstanbul Verem Savaşı Derneği, İstanbul Üniversitesi Tip Fakültesi Çapa Kampüsünde "Naile Sağlam Verem Savaş Araşırma Enstitüsü’ kurmuş̧ur (Killçarslan, Koçoğlu, 2010, s.676). Ancak İstanbul Verem Savaşı Derneği'nin yaptı̆ğ iyi niyetli çalışmaları suiistimale kalkışan bir grup ortaya çımıştır. Bunlar derneğin adııı kullanarak para toplamışlardır. Bu nedenle dernek gazeteye ilan vermek zorunda kalmıştr. İlan şu şekildedir:

"istanbul Verem Savaşı Derneği Başkanllğından: Atatürk Verem Hastanesi Yaptrrmak Derneği adına bir teşekkül makbuzlar ile bazı kimselerin para topladıklar ve birçok yerlerde İstanbul Verem Savaşı Derneğinin bu işle alakadar olduğunu söylemekte bulunduklan istihbar edilmişstir. Erenköyünde tam teşekküllü ve iki yüz yatakl bir sanatoryumu ve on dört dispanseri bulunan İstanbul Verem Savaşl Derneğinin bu şekilde bir teşebbüsü ve ne de bu nam ile para toplayan bir kolu vardrr. Böyle ir teşekkülün mevcudiyetine inanmadığımı için keyfiyet alakalı makamlara da 
1939-1950 Yılları Arasında Türkiye'de Veremle Mücadele Faaliyetleri/Ahmet Coșkun TEKINN

bildirilmiştir. Sayın vatandaşların müteyakkz bulunmaların rica ederiz (Cumhuriyet, 11.03.1949 s.6).”

İfadelerini kullanarak kamuoyunu bu konuda dikkatli davranmaya çağırmışlar ve yaşanan hadise ile ilgileri olmadığını belirtmişlerdir.

Kurulan bu dernekler diğer yerlere de örnek olmuş her geçen gün derneklerin sayısı artmıştır. 1944 yılında Denizli Veremle Mücadele Derneği kurulmuştur (Bektaş, 2006, s.204). 1946 yllında Ankara Veremle Savaş Derneği faaliyete başlamıştır (Keskinbora, 2016, s.180). 1945-1946 yıllarına arasında ülkenin dört bir yanından şehir merkezlerine hasta akınlanı başlamıştır. Dr. Tevfik Sağlam devletin veremle mücadelede yetersiz kaldığının farkında olarak daha fazla Veremle Mücadele Derneklerinin kurulması gerektiğini savunmuştur(Vidinel, 2010, s.20).

İstanbul'da 1948 yılında verem konferansı düzenlenmiş, Tevfik Sağlam öncülüğünde katılımcı 48 yerel verem savaş derneği tarafindan Türkiye Ulusal Verem Savaş Derneği, kurulmuştur (Kıllıçaraslan, Koçoğlu, 2010, s.674). Türkiye Ulusal Verem Savaş Derneği kuruluşundan hemen sonra ilk faaliyeti pul kampanyası olmuştur. Bu çalışma sayesinde ülkenin dört bir yanında veremle mücadele duyurulmuş, dernek için önemli miktarda gelir elde edilmiştir (Hisar, 2012, s.171). 15 Şubat 1950 tarihinde alınan kararla "Türkiye Ulusal Verem Savaş Derneği’' genel menfaatlere yarar derneklerden sayılmıştır (BCA 030.18.01.02/121.107.2). (Bkz. Ek:4)

İçişleri Bakanlığı kurulan Verem Savaş Derneklerini genel menfaatlere yarar dernekler kapsamına almıştır. Böylece devlet derneklere yardım yapmış ve bakanlıkla dernekler işbirliği içerisinde çalışmıştır. Örneğin 25 Mayıs 1946'da Kayseri Verem Savaş Derneği, 25 Mayıs 1946'da Ankara Verem Savaş Derneği, 13 Mart 1948'de Eskişehir Verem Savaş Derneği, 19 Nisan 1948'de Trabzon Verem Savaş Derneği, 2 Mayıs 1948'de Seyhan Verem Savaş Derneği, 5 Mayıs 1948'de Sivas Veremle Savaş Derneği, 10 Ocak 1949'da Bursa Verem Savaş Derneği, 4 Şubat 1949'da Hatay Veremle Savaş Derneği, 18 Temmuz 1951'de Düzce Verem Savaş Derneği, İçişleri Bakanlığı tarafindan genel menfaatlere yarar dernekler kapsamına almıştır . Bu gelişme devlet ve dernek işbirliğini daha da artmıştır. Hatta 1950’li yıllarda devlet verem ilaçlarını bazı zamanlarda dernekler aracılığıla ücretsiz olarak hastalara ulaştırmıştır (Özkara, 2010, s.662).

1 Temmuz 1948 tarihinde kabul edilen 5237 numaralı kanunla birliktedevlet veremle mücadeleye önemli bir destek sağlanmıştır. Çıkarılan bu kanuna göre belediyeler gece yarısından sonra açık kalacak eğlence mekânlarından aldığı verginin \% 10'unu veremle mücadeleye ayıracaktır. Belediye sınırları içerisinde verem savaş derneği varsa bu pay yardım olarak derneğe verilecek eğer böyle bir teşkilat yoksa doğrudan doğruya belediye sınırları içerisinde bulunan yoksul veremliler için harcanacaktır (Resmi Gazete, 09.07.1948, s.14348). Bu kanunla kayda değer bir adım atılmış, veremle mücadele derneklerine önemli bir maddi kaynak sağlanmıştır. 
Journal of Universal History Studies (JUHIS) • Vol. I • Issue 1 • 2018 • pp. 1-21

\section{Veremle Mücadele Konusunda Meclis Konuşmaları ve Yasal Düzenlemeler}

Verem Hastalığı birçok kez meclis gündemine de taşınmıştır. Bazı milletvekilleri verem hastalığına dikkat çeken konuşmalar yapmış, veremle mücadele konusunda önerilerde bulunmuştur. Vekiller ülke genelinde ve milletvekili seçildikleri şehirlerde verem hastaneleri kurulmasını, yeteri kadar sağlık personeli görevlendirilmesi gibi pek çok konuda görüş bildirmişlerdir.

26 Aralık 1946 tarihinde Sağılk ve Sosyal Yardım Bakanlığı bütçe görüşmeleri sırasında Rize Milletvekili Fahri Kurtuluş söz alarak; Milletvekili olduğu Rize şehrinde verem hastalkkları istatistiklerinin haddi aşıtı̆ııı belirterek konuşmasına başlamıştr. Kanunlara göre verem hastalığı oranının yüzde 6 olduğu yerlerde dispanser açılması gerektiğini, Rize'de bu oranın \% 25'e ulaştğı̆ı, ancak röntgen cihazı olmadığını ve dispanserin yetersiz olduğunu söylemiştir. Var olan eksikliklerden dolayı Sağılk Bakanlı̆ından ülke genelinde ve Rize'de veremle mücadeleye önem verilmesini rica etmiştir (TBMMTD, 26.12.1946, s.560).

Seyhan Milletvekili Dr. Makbule Dıblan ise konuşmasında; Ülkemizdeki verem hastası sayısının tahminlerden fazla olduğunu, sağlıkı olduğu düşünülen hastalara yaptı̆̆ sağlık taramasında büyük oranda verem hastalığı tespit ettiğini söylemiş̧tir. Bu hastaların muayenelerini kulakla dinleyerek yaptı̆̆ıı eğer taramayı röntgen cihazı ile yapmış olsaydı teşhis koyulan hasta sayısının daha çok olabileceğini ifade etmiştir. Veremle mücadelede en aktif sağık kuruluşunun dispanserler olduğunu ancak Sağılk Bakanlı̆̆'nın böyle önemli kuruluşa 123.000 lira gibi düşük bir bütçe ayırmasını eleştirmiş̧ir. Bir hekim olmasaydım bütçeye bakıldı̆gnda ülkemizde verem hastalı̆ı diye bir şey olmadığını düşünür ve sevinirdim ifadelerini kullanan Dr. Dıblan, verem hastalı̆ konusunda uzman doktor sayısının az olduğunu, doktorlara 40 lira gibi az bir maaş verildiğini, sağlı personelinin çok yoğun çalıştğııı söyleyerek çalışanların sorunlarıı da dile getirmiştir(TBMMTD, 26.12.1946, s.568-569).

Bütçe görüş̧meleri sırasında Sağlık ve Sosyal Yardım Bakanı Dr. Behçet Uz ise; Bakanlığın verem konusunda hassas davrandığmı, verem dispanserlerinde 37.000 hasta muayene edildiğini ve bu kişilerin 2053'ünde verem hastalı̆ı tespit edildiğini açıklamış veremle mücadele derneklerine yaptkları çalışmalardan dolayı teşekkür etmiştir. 1946 ylııın ilk dokuz ayı içinde Heybeliada Sanatoryumu ile Haydarpaşa, İzmir Bulaşıı hastalıklar hastanelerine ve Cerrahpaşa'daki Verem Koğuşu'na 3.481 verem hastasının yattığını, bunlardan 20'sinin iyileştiğini, 460'ının kurumdan ayrıldı̆̆ını, 1.337'sinin düzelme kaydettiğini ve 280 'inin öldüğünü ifade etmiştir. Veremle mücadelede önemli sağlık kuruluşları olan sanatoryum ve verem hastaneleri bakımından durumun iyi olmadığını söyleyerek öz eleştiride de bulunmuştur(TBMMTD, 26.12.1946,s.572-573).

1 Eylül 1947 tarihinde Mardin Milletvekili Dr. Aziz Uras bulaşıı hastalıklar ve veremle mücadele konusunda mecliste sağlık bakanına bir soru yöneltmiş̧tir. Dr. Uras sorusunda; trahom, tifo, kara tifo, verem, dizanteri ve bağıssak parazitleri gibi bulaşıcı hastalkklarn okullarda yayldığın, bu nedenle sağık bakanlı̆ı ile okullar arasında mevcut bir iş birliği çalışmasının olup olmadığı hakkında bilgi 
istemiştir. Bu soruya cevap olarak Bakan Dr. Uz; okulların sağlk işlerinin takip edildiğini bu amaçla illerde Sağık Müdürlükleri ve Îl Umumi Hıfzıssıhha meclislerinin, ilçelerde Hükümet, Belediye Doktorları ve İlçe Umumi Hıfzıssıhha Meclislerinin görevlendirildiğini, doktoru olan okullarda ise sağılk durumlarının bu doktorlar tarafindan takip edildiğini belirtmiştir (TBMMTD, 01.09.1947, s.549-550).

11 Nisan 1949 tarihinde TBMM'de 5368 sayllı Verem Savaşı Hakkında Kanun kabul edilmiştir. Kanunun çıkarılmasıyla birlikte veremle mücadelede somut bir adım atılmıştır. Bu kanuna göre Sağlk ve Sosyal Yardım Bakanlı̆̆ gerekli gördüğü yerlerde verem savaş teşkilatı kuracak, verem sanatoryumlan, hastaneleri, prevantoryumlanı ve dispanserleri açilacaktır. Bunlara ek olarak verem pavyonları yaptıracak ya da kiralama, kamulaştrma yahut satı alma yoluyla bu kurumlar faaliyete geçirilecektir.Veremle mücadelede kullanilacak her türlü araç, taşınabilir ya da sabit röntgen cihazları alınacaktır. Sağlk ve Sosyal Yardım Bakanlı̆ı, özel idareler ve belediyeler, verem savaş dernekleri tarafindan kurulmuş olan verem sanatoryum, prevantoryum, hastane ve dispanserlerin faaliyetlerini sürdürebilmeleri için gerekli gördügü durumlarda para ve ayni yardım yapacaktrr (Resmi Gazete, 15.04.1949, s.15966). Kanun, tasarı oylamasina katılan 249 milletvekilinin hepsinin kabul oyu ile onaylanmıştır (TBMMTD, 11.04.1949, s.287). Cumhuriyet tarihinde veremle mücadele de çıkarılan en dikkat çekici ve en önemli kanun bu olmuştur (Özkan, 2010 s.680). Kanun tasarısıla ilgili çok sayıda milletvekili konuşma yapmak için söz istemiş̧ir. Yapılan konuşmalarda kanun tasarı mecliste olumlu karşlanmıştır ve milletvekilleri bu konudaki kendi fikirlerini beyan etmiştir. Sağlık ve Sosyal Hizmetler Bakanı Kemal Beyazt konuşmacılar tarafindan takdir edilmiştir. (TBMMTD, 11.04.1949, s.240) Bu kanun tasarısı mecliste görüşüldüğü sırada Muğla Milletvekili Mithat Sakaroğlu konuyla yaptğı konuşmada şunları ifade etmiş̧ir. Tüm halkın uzun süredir beklediği veremle savaş tasarısının meclise getirilmesinden dolayı Sağlık Bakanına teşekkür etmiş, her yıl veremden 50.000 vatandaşı öldüğünü, bu konuda hazırlanmış ciddi bir istatistik çalı̧̧masının olmadığmı, mevcut hastaların ölenlerin on katı olduğunu, her hastanın hastalığını 3-5 kişiye bulaştırabileceğini söyleyerek hastalıktan kaynaklı tehlikeyi vurgulamıştır. Veremle mücadele derneklerinin imkânlarının kısttlı olduğunu, bu kısttlı imkânlara rağmen yaptklarnndan dolayı teşekkür etmiş̧ir (TBMMTD, 11.04.1949, s.240).

Kanunun kabul edilmesinden sonra Sağık Müdürü Faik Yargıı kanunla ilgili gazetecilere şu açıklamalarda bulunmuştur: $\mathrm{Bu}$ kanunla kırk iki ilde on yl içerisinde yapılması planlanan sağık kuruluşları için 20 milyon lira, yapılan binaların donanımını sağlamak için 10 milyon lira harcanmıştır. Bu amaçla her yl bütçeye 3 milyon lira ayrlacağını, İstanbul'un veremden kaynaklı en skkıntılı şehir olduğunu, başka şehirlerden gelen hastalar nedeniyle hastanelerin dolduğunu söylemiş, verem tedavisi için bekleyen binlerce insan olduğunu çıkarlan bu kanunla birlikte Sağlk Bakanlı̆ı'nın halka veremle mücadelede geniş ölçüde hizmet temin edeceğini ifade etmiş̧tir. Farklı şehirlerde kurulacak sağılk kurumları ile herkesin kendi memleketinde tedavi olabileceğini İstanbul'un ağır bir yükten kurtulacağımı belirtmiştir (Akşam, 13.04.1949, s.3). 
ISSN: 2667-4432

Journal of Universal History Studies (JUHIS) • Vol. I • Issue 1 • 2018 • pp. 1-21

\section{Sonuç}

Türkiye'de Milli Mücadele sonrasında halk sağlığını etkileyen sorunlar ortaya çıkmıştır. Bu konuda başı çeken hastalıklardan bir tanesi verem olmuştur. Verem hastalığı konusunda önemli çalışmalar başlatılmış ve hastalığın tedavisiyle ilgili gelişmeler yakından takip edilmiştir. Özellikle 1930-1937 yılları arasında veremle mücadele konusundaki çalışmalar olumlu sonuçlar vermiş ancak devlet tam anlamıyla veremle mücadele konusunda yeterli olamamıştır. II. Dünya Savaşı'nın başlamasıyla Türkiye'de ekonomik ve sosyal sıkıntılara neden olmuştur. Bu dönemde halk arasında yayılan salgın hastalıkların başında yine verem hastalı̆̆ı yer almıştır. Devletveremle mücadele için yeni sanatoryum, hastane, dispanser, pavyon gibi çeşitli sağlık kuruluşları inşa etmiştir. Nitelikli sağlık personeli yetiştirebilmek için okullar açmıştır.

Türkiye'deki verem hastalığı ve buna bağlı ölümlerin, çeşitli devletlerle kıyaslandığı istatistiksel çalışmalar incelendiğinde oranların yüksek olduğu tespit edilmiştir. Türkiye'de verem hastalı̆̆ı ve buna bağlı ölümlerle ilgili şehirler kıyaslandığında iseİstanbul ön plana çıkmaktadır. Bu süreçte İstanbul veremle mücadelede önemli merkezlerden bir tanesi olmuştur. Pek çok çalışmanın ilki İstanbul'da başlatılmıştır. Halk tedavi olabilmek için İstanbul'a gelmiştir.

Devletin çalışmalarının yetersiz kaldığı durumlarda veremle mücadele dernekleri devreye girmiştir. Dernek çalışmalarının yararlarının farkında olan devlet yöneticileri derneklerin çalışmalarını kolaylaştıracak destekler sağlamıştır. Hatta bazı zamanlarda devlet dernekler aracılığıyla veremle mücadele etmiştir. $\mathrm{Bu}$ sayede verem hastalığının ortadan kaldırılması konusunda olumlu gelişmeler yaşanmıştır. Yaşanan bu gelişmeler Sivil toplum kuruluşlarıyla işbirliğinin önemini ortaya çıkarmıştır. 


\section{Kaynakça}

[1] BCA, 030.18.01.01/29.44.18

[2] BCA, 030.00.00.00/179.235.24

[3] BCA, 030.01.00.00/77.482.6

[4] BCA, 030.01.00.00/77.482.6.1

[5] BCA, 030.01.00.00/77.482.6.5

[6] BCA, 030.01.00.00/77.482.6.6

[7] BCA, 030.18.01.02/109.59.9

[8] BCA, 030.18.01.02/11.31.14

[9] BCA, 030.18.01.02/111.37.8

[10] BCA, 030.18.01.02/111.37.9

[11] BCA, 030.18.01.02, 116.19.17

[12] BCA, 030.18.01.02/116.28.2

[13] BCA, 030.18.01.02/116.31.6

[14] BCA, 030.18.01.02/116.38.2

[15] BCA, 030.18.01.02/116.38.7

[16] BCA, 030.18.01.02/118.87.13

[17] BCA, 030.18.01.02/118.96.15

[18] BCA, 030.18.01.02/121.107.2

[19] BCA, 030.18.01.02/126.55.5

[20] BCA, 490.01.00.00/08.41.4

[21] BCA, 030.18.01.02/121.107.3

[22] BCA, 030.18.01.02/30.59.8

[23] TBMMTD, 26 Aralık 1946

[24] TBMMTD, 1 Eylül 1947

[25] TBMMTD, 11 Nisan 1949

[26] Resmi Gazete, 6 Mayıs 1930 
[27] Resmi Gazete, 9Temmuz 1948

[28] Resmi Gazete, 15 Nisan 1949

[29] Akşam Gazetesi, 13 Nisan 1949

[30] Cumhuriyet Gazetesi, 11 Temmuz 1939

[31] Cumhuriyet Gazetesi, 17 Temmuz 1940

[32] Cumhuriyet Gazetesi, 6 Arallk 1940

[33] Cumhuriyet Gazetesi, 20 Temmuz 1941

[34] Cumhuriyet Gazetesi, 25 Temmuz 1941

[35] Cumhuriyet Gazetesi, 7 Ekim 1948

[36] Cumhuriyet Gazetesi, 2 Kasim 1948

[37] Cumhuriyet Gazetesi, 10 Kasım 1948

[38] Cumhuriyet Gazetesi, 13 Kasim 1948

[39] Cumhuriyet Gazetesi, 1 Aralık 1948

[40] Cumhuriyet Gazetesi, 9 Arallk 1948

[41] Cumhuriyet Gazetesi, 20 Aralık 1948

[42] Cumhuriyet Gazetesi, 10 Şubat 1949

[43] Cumhuriyet Gazetesi, 24 Şubat 1949

[44] Cumhuriyet Gazetesi, 11 Mart 1949

[45] Cumhuriyet Gazetesi, 23 Mart 1949

[46] Cumhuriyet Gazetesi, 29 Ocak 1950

[47] Kasapoğlu, Aytül(2016), “Türkiye'de Sağlık Hizmetlerinin Dönüşümü”, Sosyoloji Araştırmaları Dergisi, Sayı 19(2).

[48] Altun, Didem Akyol(2014), "Cumhuriyet Öncesi Dönemde İzmir Hastanelerinin Mekânsal Gelişimi”, Tarih Incelemeleri Dergisi, Sayı: 2.

[49] Tuğluoğlu, Fatih(2008), "Cumhuriyetin Illk Döneminde Verem Mücadelesi ve Propaganda Faaliyetleri”, Yakn Dönem Türkiye Araşstrmaları, Sayı: 13-14.

[50] Hisar, Filiz ve Hisar, Kemal Macit, (2012), "Türkiye'deki Sağlık Politikalanı ve Tüberküloz Kontrolü Üzerine Etkisi’, Sürekli Tip Eğitim Dergisi(STED). 
[51] Özkaya, Hilal(2016), “Cumhuriyet Döneminde Bulaşıcı Hastalıklarla Mücadele”, Türkiye Aile Hekimliği Dergisi, Sayı 2.

[52] İleri, Hüseyin; Seçer, Betül, vd.(2016), "Sağlık Politikası Kavramı ve Türkiye'de Sağlık Politikalarının İncelenmesi”. Selçuk Üniversitesi Sosyal ve Teknik Araştırmalar Dergisi, Sayr:12.

[53] Vidinel, İlhan(2010), Türkiye'de Tüberküloz Hastalığına Tarihsel Bir Bakaş, Toraks Kitapları Tüberküloz, AVES Yayıncılık, İstanbul.

[54] Bektaş, İzzettin(2006), "Sözlü Tarihin Tanıklığında Cumhuriyet Döneminde Buldan'da Verem Gerçeği ve Veremle Mücadele”. Buldan Sempozyumu, Denizli.

[55] Keskinbora, Kadircan(2016), "Savaşsaki Düşmanlardan Bir Diğeri: Tüberküloz', Mersin Üniversitesi Tip Fakültesi Lokman Hekim Tip Tarihi ve Folklorik Tip Dergisi, 6(3).

[56] Gürgan, Mahmut(2013), “Cumhuriyetin İlk Yıllarında, İzmir Veremle Mücadele Cemiyeti’nin Propaganda Faaliyetler’”, İzmir Gögüs Hastanesi Dergisi, Sayı 2.

[57] Çufal1, Mustafa(2012), Türk Parlamento Tarihi: TВMМ VIII. Dönem (1946-1950), Türkiye Büyük Millet Meclisi Yayınları. Cilt:1, Ankara.

[58] Dokuyan, Sabit(2013), "İkinci Dünya Savaşı Sırasında Yaşanan Gıda Sıkıntısı ve Ekmek Karnesi Uygulaması", Electronic Turkish Studies, 8(5).

[59] Sağllk Bakanlı̆̆ Tedavi Hizmetleri Genel Müdürlügüu(2004), 80. Yılda Tedavi Hizmetleri (1923-2003), Ankara.

[60] Özkan, Suha(2010), Ülkemizde Verem Savaşının Temel Kuruluşu: Verem Savaşı Dispanseri, Toraks Kitaplan Tüberküloz. AVES Yayıncılık, İstanbul.

[61] Özkara, Şeref(2010), Türkiye’de Tüberküloz Epidemiyolojisi, Toraks Kitapları Tüberküloz, AVES Yayıncılı, İstanbul.

[62] Özkara, Şeref; Aktaş, Zafer vd.(2003), Türkiye'de Tüberkülozun Kontrolü Için Başvuru Kitabl, TC Sağlık Bakanlığı Verem Savaş Daire Başkanlığı, Ankara.

[63] Kilıçarslan, Zeki ve Koçoğlu, Ferit(2010), Türkiye'de Verem Savaşııda Derneklerin Rolü, Toraks Kitapları Tüberküloz, İstanbul, AVES Yayıncılık.

[64] Çakırçoban, İsmail(2010), İkinci Dünya Savaşı'nda Türkiye'de Bulaşıcı Hastalıklarla Mücadele, Marmara Üniversitesi, İstanbul. (Yayınlanmamış Yüksek Lisans Tezi)

[65] Kayış, İlyas(2009), İkinci Dünya Savaşı'nda Türkiye'nin Genel Durumu ve Uyguladı̆̆ Dış Politika, Beykent Üniversitesi, İstanbul. (Yayınlanmamış Yüksek Lisans Tezi) 
ISSN: 2667-4432

Journal of Universal History Studies (JUHIS) • Vol. I • Issue 1 • 2018 • pp. 1-21

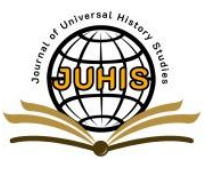

[66] Hot, İnci(2001), Sihhiye Mecmuasına Göre Ülkemizde Bulaşıcı Hastalılarla Mücadele (1913-1996), İstanbul Üniversitesi, İstanbul. (Yayınlanmamış Doktora Tezi)

[67] Y1lmaz, Kerem(2014), Tarihsel Süreçte Sanatoryum Heybeliada Devlet Sanatoryumu, Marmara Üniversitesi, İstanbul. (Yayınlanmamış Doktora Tezi) 
Ekler

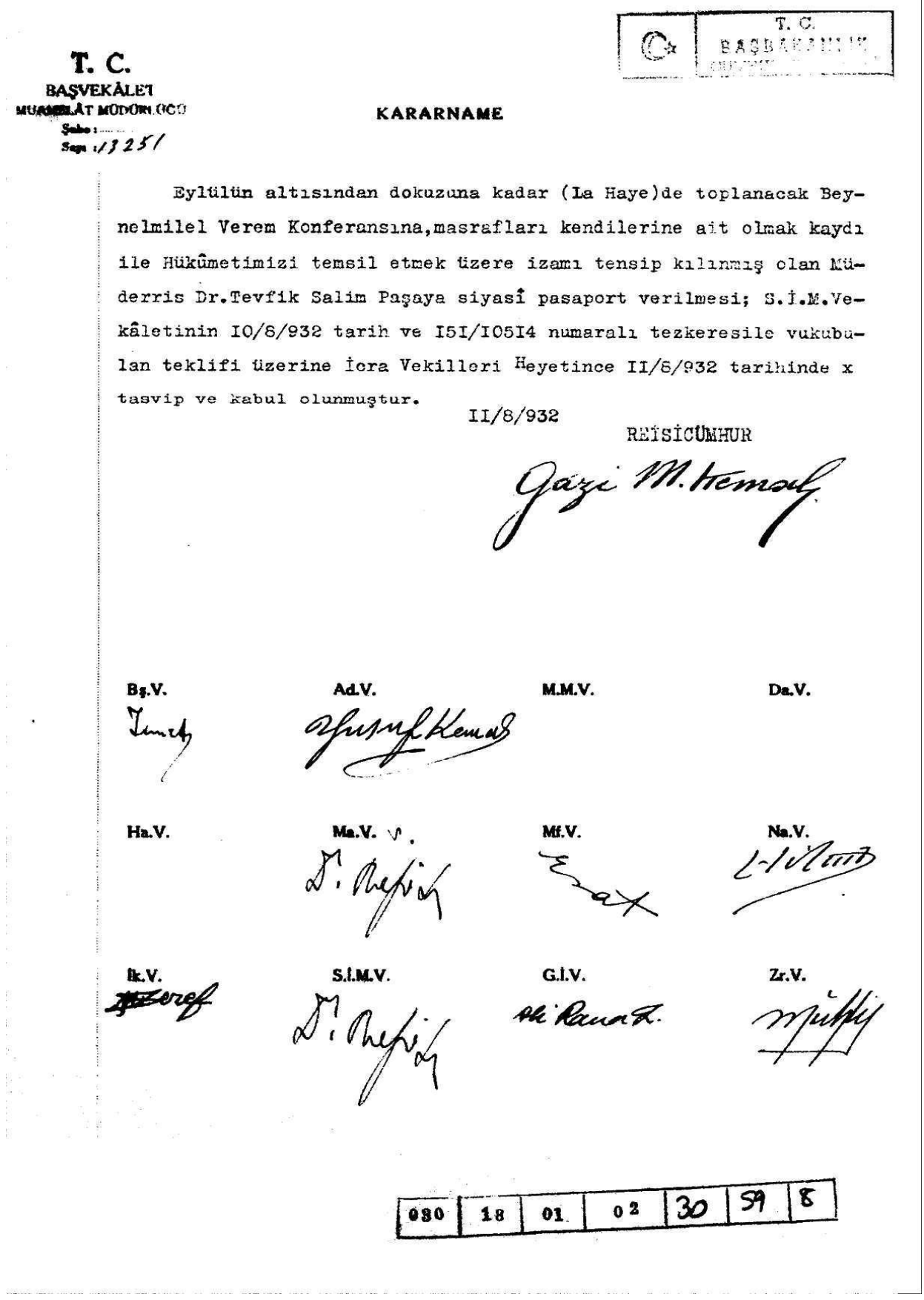

EK 1. Lahey'de toplanacak Uluslararası Verem Konferansı'na katılacak olan Dr. Tevfik Salim Paşa'ya siyasi pasaport verilmesi hakkında kararname. 
Journal of Universal History Studies (JUHIS) • Vol. I • Issue 1 • 2018 • pp. 1-21

1942 yzinda

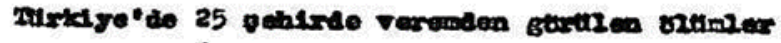

\begin{tabular}{|c|c|c|c|}
\hline 3antredz. & $\begin{array}{l}\text { thrug } \\
\text { (1940) }\end{array}$ & $\begin{array}{l}\text { Verenden rzum } \\
\text { odede } 2942 \\
\end{array}$ & $\begin{array}{l}\text { Yerom silluth } \\
(200.000 \mathrm{ca})\end{array}$ \\
\hline Mane & 63,229 & 259 & 130.4 \\
\hline Argon & 25.897 & 34 & 231.2 \\
\hline Mraxe & 157,242 & 299 & 290.2 \\
\hline inta2sa & 24.957 & 32 & 224.2 \\
\hline ardsen & 17,732 & 32 & 280.4 \\
\hline Balukeals & 30,220 & 94 & 322.2 \\
\hline Murea & 77.590 & 295 & 380.2 \\
\hline Genneirtiele & 24,622 & 102 & 420.2 \\
\hline Ginnkses & 10.235 & 23 & 227,0 \\
\hline Sorrum & 22,776 & 22 & 96.5 \\
\hline Denterl & 19,462 & 18 & 92.4 \\
\hline DEsarbalar & 42.525 & $6 \mathbf{2}$ & 243.4 \\
\hline Enkelocher & 66,742 & 270 & 279,8 \\
\hline Gandentery & 57,132 & 68 & 129,0 \\
\hline Igex & 30,007 & 29 & 96.6 \\
\hline Iopearta & 28,313 & 36 & 297.6 \\
\hline Istenbul & 793.949 & 2,534 & 329.2 \\
\hline Inment & 283,762 & 608 & 330.8 \\
\hline Enxzlare21 & 32,232 & 23 & $71 \cdot 3$ \\
\hline roesals & 39,120 & an & 278.2 \\
\hline rongra & 56.465 & 107 & 289.4 \\
\hline anteloya & 18,297 & 32 & 274.8 \\
\hline Handan & 37,623 & 78 & 207.3 \\
\hline Sarneun & 37,216 & 237 & 368.2 \\
\hline Takdxan & 37.082 & 22 & 20. \\
\hline 20p2= & $2,913,202$ & 5,083 & 265,6 \\
\hline
\end{tabular}

\begin{tabular}{|l|l|l|l|l|l|l|}
\hline 030 & 01 & & & 77 & 482 & 6 \\
\hline
\end{tabular}

EK 2: 1942 yllında Türkiye'de Veremden Ölenlerin İstatistik Çalış̧ası 


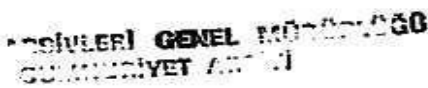

Iiste. 1

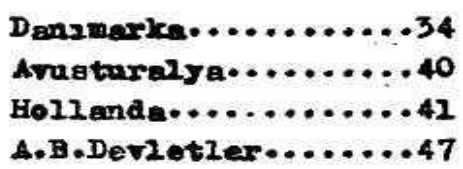

2946 griznda Wasington Publ1e Healt raporlarina nasaran 1x lasim memleketlerde 100 bli ntifuata verenden blenlex .

\begin{tabular}{|l|l|l|l|l|l|l|}
\hline 030 & 01 & & & 77 & 482 & 6 \\
\hline
\end{tabular}

EK:3 1946 yılında Washington Public Health çalışmaları sonucunda hazırlanan bazı ülkelerde 100.000 kişide veremden ölüm oranları hakkında istatistik raporu. 
Journal of Universal History Studies (JUHIS) • Vol. I • Issue 1 • 2018 • pp. 1-21

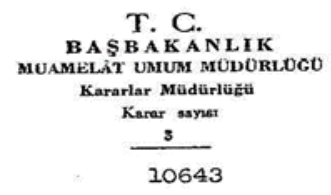

KARAR

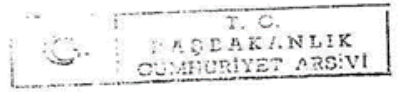

"Tükiye Ulusal verem Sevaş Derneğinin genel menfaetlere yarar derneklerden sayılmesi, Işisleri Bskenlığnin 8I/I75/734 spylli ve IO/IZ/I949 tarihli yezlsı ve Denlştay Genelkurulunun 49/28I/28 seylll ve I9/I/I950 tarihli kararl uzerine, 35I2 sayll1 kanunun 37 nei meddesine göre, Bakanlar Kurulunce 15 / 2 /reso terihinde karerlastırilmistur.

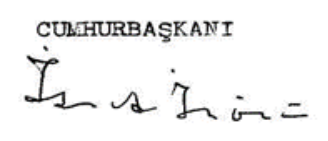

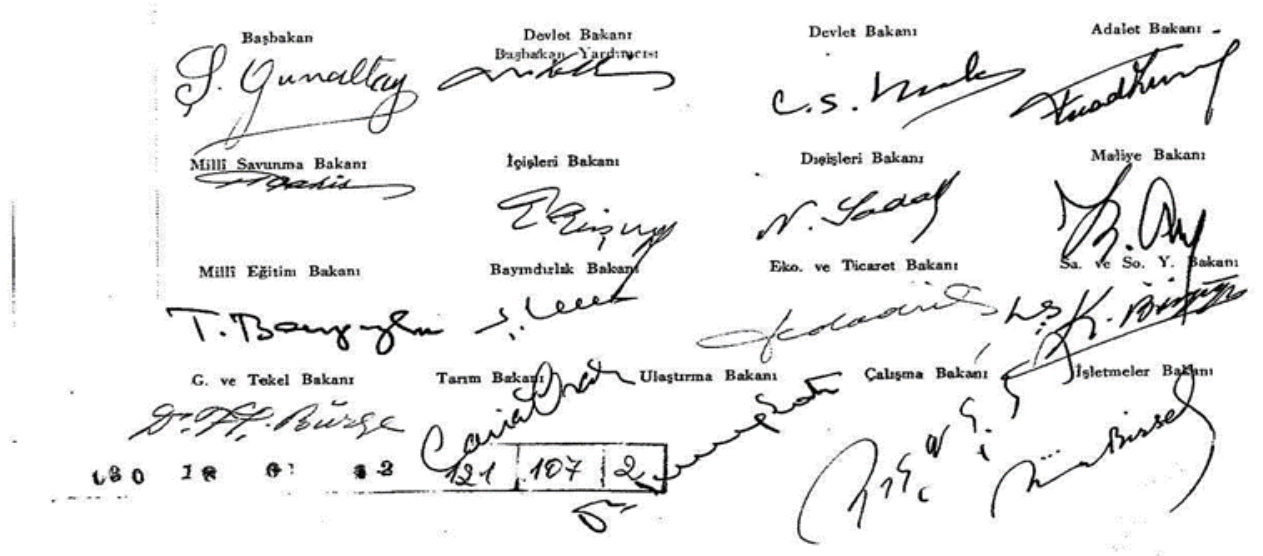

EK 4: Türkiye Ulusal Verem Savaş Derneği'nin kamuya yararlı derneklerden sayılması hakkında kararname 